DOI:10.17951/h.2021.55.1.67-84

\begin{tabular}{lc}
\hline \multicolumn{1}{c}{ A N N A L E S } \\
UNIVERSITATIS MARIAE CURIE-SKŁODOWSKA \\
LUBLIN - POLONIA \\
SOL. LV, 1 & SECTIO H \\
\hline
\end{tabular}

MIROSŁAW SOŁTYSIAK

miroslaw@prz.edu.pl

Politechnika Rzeszowska. Wydział Zarządzania

al. Powstańców Warszawy 10, 35-959 Rzeszów, Polska

ORCID ID: https://orcid.org/0000-0003-3366-1537

\title{
Waluta lokalna - empiryczna analiza poziomu znajomości i akceptacji wśród przedstawicieli młodego pokolenia
}

Local Currency - an Empirical Analysis of the Level of Knowledge and Acceptance among the Representatives of the Young Generation

Keywords: local currency; issue; young generation of Poles

Słowa kluczowe: waluta lokalna; emisja; młode pokolenie Polaków

JEL: G21

Propozycja cytowania: Sołtysiak, M. (2021). Waluta lokalna - empiryczna analiza poziomu znajomości i akceptacji wśród przedstawicieli młodego pokolenia. Annales Universitatis Mariae Curie-Skłodowska, sectio H-Oeconomia, Vol. 55, No. 1.

\footnotetext{
Abstract

Theoretical background: The issue of the functioning of local currencies is very rarely discussed in Polish literature, there are no comprehensive studies on this subject. Currently, there are several thousand local currencies in the world, the issue of which is aimed at stimulating the local economy. In Poland, there are also attempts to introduce local currencies into circulation. Therefore, it is important to examine the attitude of citizens to such a currency.

Purpose of the article: Determining the level of knowledge of issues related to the functioning of local currencies among representatives of the young generation of Poles and examining their attitudes regarding the introduction of such currency to the market.
} 
Research methods: The analysis of the level of knowledge and acceptance of local currencies among the representatives of the young generation of Poles was based on own research and a review of the literature on the subject. The data used in the analysis was obtained from a survey conducted on a group of 784 respondents aged 18-25, carried out in the period from January to February 2020.

Main findings: The conducted research allowed to state that among the representatives of the young generation of Poles, the issues related to the functioning of the local currency are known to a minimum degree. Almost half of them believe that there was no need to introduce an additional supplementary currency in their place of residence. Almost $25 \%$ of respondents declared their willingness to make payments in the local currency, which allows to state that in Poland there are opportunities for the development of local currencies. The issuers of such a currency should be entities with a high level of social trust and state guarantees. According to the respondents, the best method to carry out transactions using local currency is an electronic form.

\begin{abstract}
Abstrakt
Uzasadnienie teoretyczne: Zagadnienie funkcjonowania walut lokalnych jest bardzo rzadko poruszane w literaturze polskiej, brak jest całościowych opracowań na ten temat. Aktualnie na świecie funkcjonuje kilka tysięcy walut lokalnych, których emisja ma na celu pobudzenie lokalnej gospodarki. W Polsce również podejmowane są próby wprowadzenia do obiegu walut lokalnych, dlatego istotne jest zbadanie, jaki stosunek do takiej waluty mają obywatele.

Cel artykułu: Określenie poziomu znajomości zagadnień związanych z funkcjonowaniem walut lokalnych wśród przedstawicieli młodego pokolenia Polaków oraz zbadanie ich postawy odnośnie do wprowadzenia do obrotu takiej waluty.

Metody badawcze: Analiza poziomu znajomości i akceptacji walut lokalnych wśród przedstawicieli młodego pokolenia Polaków została oparta na badaniach własnych i przeglądzie literatury przedmiotu. Dane wykorzystane w analizie uzyskano z badania ankietowego przeprowadzonego na grupie 784 respondentów w wieku 18-25 lat w okresie od stycznia do lutego 2020 roku.

Główne wnioski: Przeprowadzone badania pozwoliły stwierdzić, że wśród przedstawicieli młodego pokolenia Polaków zagadnienia związane z funkcjonowaniem waluty lokalnej są znane w minimalnym stopniu. Prawie połowa z nich uważa, że w miejscu ich zamieszkania nie ma potrzeby wprowadzania dodatkowej waluty uzupełniającej. Niemal $25 \%$ respondentów zadeklarowało chęć dokonywania płatności w walucie lokalnej, co pozwala na stwierdzenie, że w Polsce istnieją możliwości do rozwoju walut lokalnych. Emitentami takiej waluty powinny być podmioty posiadające wysoki poziom zaufania społecznego oraz gwarancje państwowe. Zdaniem ankietowanych najlepsza do realizacji transakcji przy pomocy waluty lokalnej jest forma elektroniczna.
\end{abstract}

\title{
Wprowadzenie
}

Idea waluty lokalnej nie jest zjawiskiem nowym, z tego typu środkami płatniczymi można było bowiem spotkać się w różnych miejscach na świecie na przestrzeni wieków ${ }^{1}$. Za protoplastę współczesnych walut lokalnych uważane są wyemitowane 90 lat temu w austriackim mieście Wörgl bony pracy znane pod nazwą szylingów Wörgl. Podstawowym celem wprowadzenia do obrotu tej waluty uzupełniającej było pobudzenie lokalnej gospodarki.

1 Na przestrzeni wieków emitentami takich walut byli lokalni władcy, biskupi oraz samorządy miast. 
Współcześnie również jest to jeden z podstawowych celów wprowadzenia waluty lokalnej. W dobie globalizacji rośnie w lokalnych społecznościach pragnienie umocnienia więzi występujących pomiędzy mieszkańcami oraz stworzenia społeczeństwa obywatelskiego, które poprzez wspólne działanie może mieć wpływ na rozbudowę lokalnej przedsiębiorczości czy zwiększenie zamożności mieszkańców. W realizacji tych działań może być pomocna waluta lokalna (por. Ranalli, 2013). Może ona stanowić nie tylko alternatywną formę zapłaty za produkty i usługi stworzone przez przedstawicieli lokalnej społeczności, lecz także może być czynnikiem mającym znaczący wpływ na poprawę wyników lokalnej gospodarki ${ }^{2}$ oraz narzędziem pozwalającym na zmniejszenie poziomu ryzyka związanego z ucieczką kapitału $\mathrm{z}$ lokalnego rynku.

Wiele osób, widząc we wprowadzeniu waluty lokalnej skuteczne narzędzie na zażegnanie kryzysu, nie dostrzega, że osiągnięcie sukcesu gospodarczego przy jej wykorzystaniu nie jest zjawiskiem prostym i udaje się tylko nielicznym regionom. Na początku XXI wieku został zauważony dynamiczny wzrost zainteresowania uruchamianiem takich emisji ${ }^{3}$. Co roku w wielu regionach na całym świecie, zarówno w małych miejscowościach, jak i w dużych aglomeracjach, wprowadzana jest do obrotu waluta lokalna ${ }^{4}$. Okres funkcjonowania takiej waluty zazwyczaj jest jednak bardzo krótki. Może to być wynikiem m.in.: niedostatecznych działań edukacyjnych mających na celu przygotowanie partnerów biznesowych i konsumentów do posługiwania się równocześnie walutą narodową i walutą alternatywną; brakiem odpowiedniej sieci podmiotów akceptujących taką walutę; niskim poziomem zainteresowania lokalnych konsumentów korzystaniem z waluty lokalnej; wyemitowaniem nieadekwatnej do lokalnych potrzeb ilości takiej waluty. Kluczowym czynnikiem sukcesu (obok czynników ekonomicznych) emisji waluty lokalnej jest zatem zaufanie do niej członków lokalnej społeczności. Dlatego istotnym zagadnieniem jest przeprowadzenie badań dotyczących poziomu wiedzy oraz nastawienia do takiego rodzaju waluty uzupełniającej w społeczeństwie.

Celem niniejszego artykułu jest prezentacja wyników badań, które miały pozwolić na określenie poziomu znajomości zagadnień związanych z funkcjonowaniem walut lokalnych wśród przedstawicieli młodego pokolenia mieszkańców Polski, a także zbadanie ich postawy odnośnie do wprowadzenia do obrotu takiej waluty.

2 Zdaniem Swann i Witt (1995) waluty lokalne mogą odgrywać istotną rolę w rozwoju stabilnego, zróżnicowanego regionu. Ponadto zachęcają one do bezpośrednich transakcji pomiędzy sąsiadami. Są one zarówno narzędziem ekonomicznym, jak i narzędziem kulturowym.

3 Dla przykładu we Francji po 2010 roku wprowadzono do obiegu ponad 80 walut lokalnych.

4 Waluty takie emitują małe miejscowości, jak np. czeska gmina Křižánky, którą zamieszkuje tylko 370 stałych mieszkańców, a także duże aglomeracje, jak np. stolica Francji - Paryż. 


\section{Istota waluty lokalnej}

Waluta lokalna ${ }^{5}$ to waluta akceptowana na ograniczonym terytorium. Jej emitentem nie jest podmiot posiadający $\mathrm{w}$ danym państwie prawo emisji pieniądza, $\mathrm{w}$ związku z tym nie jest ona prawnym środkiem płatniczym. Funkcjonuje jako waluta uzupełniająca w stosunku do waluty krajowej, zamiast ją zastępować (Sołtysiak, 2020, s. 68). Waluta ta jest określana jako alternatywne narzędzie płatnicze stworzone przez lokalne społeczności w celu pośrednictwa między lokalnymi procesami biznesowymi. Jej funkcjonowanie w obrocie gospodarczym wymaga współpracy podmiotów gospodarczych i partnerów oraz chęci do jej akceptacji wśród partnerów biznesowych i konsumentów (Collom, 2011). Podstawowym celem jej wprowadzenia jest zwiększenie obrotów lokalnych podmiotów gospodarczych, które zgodziły się ją przyjmować jako zapłatę za sprzedawane towary lub świadczone usługi (Sołtysiak, 2020, s. 68).

Zdaniem Kennedy, Lietaera i Rogersa (2012, s. 57) dobrze zaprojektowana waluta lokalna może pozwolić na realizację takich celów, jak:

1) selektywne pobudzanie regionalnej gospodarki,

2) rozwój trwałego systemu finansowego, zapewniającego lepszą ochronę przed skutkami spekulacji finansowych,

3) zapewnienie nowych źródeł płynności, zwłaszcza dla małych i średnich przedsiębiorstw, co prowadzi do ekspansji ich produktów i usług na regionalnych rynkach,

4) tworzenie miejsc pracy,

5) zwiększenie potencjału tworzenia wartości dodanej i nadwyżki w regionie,

6) bliższe kontakty między producentami a konsumentami - krótsze odległości transportu i mniejsze zużycie energii,

7) outsourcing i koprodukcja usług publicznych na rzecz organizacji ekonomii społecznej: spółdzielni, organizacji charytatywnych, przedsiębiorstw społecznych,

8) wzmocnienie tożsamości regionalnej i postaw samopomocowych, które może przynieść wiele innych korzystnych zmian.

Zdaniem tych autorów waluty regionalne działają na biedniejszych i bogatszych obszarach na różne sposoby. Ludzie, którzy są biedni, ale mają dużo czasu, mogą zamienić swoje umiejętności i usługi na walutę, aby kupić żywność i inne podstawowe produkty. Natomiast osoby posiadające gotówkę, ale odczuwające brak czasu, mogą kupować lokalną walutę zabezpieczoną w walucie krajowej i w taki sposób wspierać lokalną gospodarkę (Kennedy, Lietaera, \& Rogers, 2012, s. 55-56).

W zależności od obowiązujących $\mathrm{w}$ danym państwie przepisów dotyczących emisji pieniądza emitentami waluty lokalnej mogą być władze publiczne, fundacje ${ }^{6}$,

5 Pojęcie waluty lokalnej odnosi się do pieniądza używanego na danym niedużym obszarze (np. miasto, powiat, region), ale niebędącego pieniądzem narodowym. Należy zaznaczyć, że literaturze przedmiotu, szczególnie anglojęzycznej, termin ten czasami jest używany również w odniesieniu do mniej płynnych walut narodowych.

6 Przykładem może być Fundacja Zeitvorsorge, która działa w mieście St. Gallen. 
przedsiębiorstwa ${ }^{7}$, spółdzielnie, stowarzyszenia ${ }^{8}$, a nawet osoby fizyczne ${ }^{9}$ lub grupy osób. Waluty te funkcjonują zarówno $\mathrm{w}$ formie materialnej ${ }^{10}$, jak i w formie elektronicznej ${ }^{11}$. Ich wartość może zostać odniesiona do wartości jednostki waluty narodowej lub do innej jednostki posiadającej wartość, np. godziny pracy ${ }^{12}$ lub płodów rolnych ${ }^{13}$. W większości przypadków pomimo odniesienia wartości waluty lokalnej do wartości waluty krajowej nie ma możliwości jej swobodnej wymiany na tę walutę ${ }^{14}$ lub dokonanie takiej wymiany związane jest z poniesieniem dodatkowych kosztów. Dla podniesienia poziomu wiarygodności takiej waluty podmiot ją emitujący powinien złożyć w instytucji zaufania publicznego depozyt zabezpieczający w wysokości adekwatnej do wielkości emisji ${ }^{15}$.

Do podstawowych cech waluty lokalnej należy zaliczyć:

1) bezodsetkowość - nie generuje ona długu, a jedynie koszty związane z utrzymaniem systemu transakcyjnego,

2) otwartość - każdy zainteresowany członek danej społeczności, niezależnie od tego, czy jest to podmiot gospodarczy czy osoba fizyczna, może korzystać z tej waluty,

3) zamknięty obieg - waluta jest honorowana na ograniczonym obszarze tylko przez podmioty, które wyraziły na to zgodę,

4) wymuszony obieg - waluta lokalna ma zazwyczaj określony termin ważności, którego przedłużenie związane jest z ponoszeniem dodatkowych kosztów (ujemne oprocentowanie),

${ }^{7}$ The Walt Disney Company wyemitował walutę Disney Dollars, którą można było płacić w Disneylandzie oraz w Walt Disney World.

${ }^{8}$ Stowarzyszenie Cairn dokonało emisji waluty lokalnej Cairn w Grenoble. Stowarzyszenie Une monnaie pour Paris rozpoczęło w dniu 12 maja 2018 roku emisję lokalnej waluty w Paryżu.

${ }^{9}$ Na przykład rosyjski rolnik Szkłanikow wyemitował w 2014 roku walutę lokalną o nazwie Kolion.

${ }_{10} \mathrm{~W}$ formie materialnej są emitowane np. BerkShares, Brixton Pound, Bristol Pound.

11 Przykładem waluty lokalnej, która funkcjonuje wyłącznie w formie elektronicznej, jest WIR frank, a także obywatelska waluta Barcelony Rec, z której można korzystać, wyłącznie używając aplikacji mobilnej dostępnej w Google Play i Apple Store.

12 Tego typu waluty lokalne najczęściej są kreowane przez tzw. banki czasu, czyli instytucje samopomocowe pośredniczące w bezpłatnej wymianie usług pomiędzy uczestnikami projektu. Ideę tego typu instytucji oraz określenie „waluty społeczne” (Timedollars) opracował w 1980 roku Edgar Cahn. Przykładami walut społecznych mogą być japońska waluta Fureai kippu, szwajcarska waluta Zeitvorsorge czy nieistniejąca już waluta Ithaca Hour, która była wykorzystywana w amerykańskim stanie Nowy Jork. Należy również zaznaczyć, że w 1950 roku Teruko Mizushima, zaprezentował ideę opartej na czasie waluty komplementarnej oraz banku czasu (Lietaer, 2004).

${ }_{13}$ Wartość waluty lokalnej Kolion, emitowanej w latach 2014-2015 w rosyjskim miasteczku Kolionow, została ustalona dla 1 Koliona na poziomie ceny $10 \mathrm{~kg}$ ziemniaków, a dla 2 Kolionów odpowiadała cenie 10 jaj. Natomiast Wendell Berry, amerykański poeta i jeden z liderów drobnych rolników, zaproponował, żeby wartość waluty lokalnej w Kentucky została określona na podstawie wartości kurczaka (Swann \& Witt, 1995).

14 Jedynie w ustawodawstwie francuskim obowiązuje od 1 sierpnia 2014 roku przepis mówiący o możliwości dokonywania wymiany waluty lokalnej na euro (zob. www2, art. 16).

${ }^{15} \mathrm{Z}$ takiej formy zabezpieczenia skorzystało miasto Wörgl, dokonując pierwszej historycznej emisji pieniądza lokalnego. 
5) większą szybkosśc obiegu ${ }^{16}$,

6) demokratyczny charakter - wszyscy członkowie systemu mają dostęp do informacji i sprawują kontrolę,

7) komplementarność - waluty lokalne stanowią uzupełniający dla waluty krajowej środek płatniczy,

8) powiązanie wartości waluty lokalnej zazwyczaj z walutą krajową w stosunku jeden do jednego lub z wartością godziny pracy.

Do zalet wykorzystywania systemu waluty lokalnej można zaliczyć (Lietaer, 1999; Kennedy \& Lietaer, 2004; Tóth, 2011):

1) waluta lokalna może oddziaływać na rozwój lokalnych społeczności, umożliwia przedsiębiorstwom z sektora MŚP, rolnikom, lokalnym rzemieślnikom $i$ handlowcom aktywny udział w lokalnych inicjatywach,

2) waluta lokalna krąży szybciej niż waluta krajowa, co pozwala na osiągnięcie wyższych dochodów w określonym czasie,

3) waluty uzupełniające ułatwiają bardziej ekonomiczną produkcję, a także zaspokajają wyjątkowe potrzeby lokalne i regionalne,

4) waluta lokalna sprzyja współpracy między podmiotami gospodarczymi bez wcześniejszych stosunków handlowych oraz wzmacnia istniejące kooperacje, a tym samym tworzy bardziej sprzyjające środowisko dla innowacji i rozwoju,

5) system waluty lokalnej pozwala na częściowe pomijanie środków rozwojowych spoza regionu i sprzyja rozwojowi endogenicznemu,

6) waluta lokalna poprawia morale płatnicze uczestników, ponieważ posiadacze instrumentu nie uzyskują żadnej korzyści poprzez zatrzymanie waluty lokalnej i nie czerpią żadnych zysków z jej akumulacji,

7) wspierając opiekę zdrowotną, edukację i ochronę środowiska, system waluty lokalnej może ułatwić lepsze wykorzystanie potencjału regionu oraz umiejętności i doświadczenia.

Natomiast do negatywnych aspektów związanych z wprowadzeniem waluty lokalnej należy zaliczyć (Lietaer, 1999; Kennedy \& Lietaer, 2004; Tóth, 2011):

1) konieczność utworzenia organizacji non-profit dla zrównoważonego funkcjonowania systemu waluty lokalnej. Organizacja ta musi sporządzić rejestr popytu i podaży, który będzie wymagał ciągłej aktualizacji, na temat przedsiębiorstw i organizacji non-profit znajdujących się w systemie waluty lokalnej,

2) na wstępnym etapie trudność przekonania lokalnych przedsiębiorców do współpracy w ramach systemu waluty lokalnej. Na kolejnym etapie trudności związane ze zmotywowaniem interesariuszy i zarządzaniem komunikacją między nimi,

${ }^{16}$ Dla przykładu szybkość obiegu waluty lokalnej Chiemgauer była od 2,5 do 3 razy większa niż euro (Volkmann, 2012). Natomiast szybkość obiegu Bristol Pound jest 10 razy większa niż brytyjskiego funta (GBP) (www6). 
3) łatwy dostęp do lokalnej waluty, przy czym oszczędne wydatki wymagają przemyślanych, przyszłych decyzji,

4) system waluty lokalnej daje wrażenie, że podmioty należące do sektora MŚP są w stanie konkurować z silniejszymi, krajowymi, wielonarodowymi lub ponadnarodowymi korporacjami,

5) sukces systemu walutowego w dużej mierze zależy od zachowania interesariuszy oraz od płynności,

6) w przypadku korzystania z systemu waluty lokalnej konsumpcja ma pierwszeństwo przed oszczędnościami. Wzrostowi konsumpcji towarzyszy jednak krótkookresowy wzrost gospodarczy, który nie wpływa znacząco na poprawę jakości życia.

\section{Przyklady walut lokalnych}

Aktualnie na świecie w obrocie gospodarczym funkcjonuje ponad 6000 walut lokalnych. Co roku pojawiają się nowe waluty, których żywot przeważnie nie trwa dłużej niż kilka lat. Należy podkreślić, że w obrocie gospodarczym funkcjonują również takie waluty, których historia sięga lat trzydziestych ubiegłego wieku.

Za pierwszą walutę lokalną jest uważany szyling Wörgl (Wörgler Schilling), określany potocznym mianem freigeld (wolny pieniądz). Był on emitowany przez austriackie miasto Wörgl w formie banknotów (tzw. bonów pracy) od 5 lipca 1932 roku do sierpnia 1933 roku. Waluta ta posiadała sztywny kurs w stosunku do austriackiego szylinga. Związane było z nią ujemne oprocentowanie (demurrage - okresowe zmniejszenie jej wartości). W praktyce posiadaczom tej waluty zależało więc na szybkim jej wykorzystaniu w transakcjach handlowych, a nie na utrzymywaniu w niej oszczędności. Należy podkreślić, że władze miejskie dla zwiększenia poziomu zaufania do tej lokalnej waluty złożyły zabezpieczenie w austriackich szylingach w lokalnej Raiffeisenkass (www3; www4; www5; www8).

W 2020 roku najdłużej funkcjonującą na rynku walutą lokalną był WIR frank. Ta prywatna waluta jest emitowana od 1934 roku w Szwajcarii. Jej emitentem jest założony przez Wernera Zimmermanna i Paula Enza WIR Bank (pierwotnie Swiss Economic Circle). Aktualnie jest elektroniczną walutą nieposiadającą formy materialnej (pieniądza papierowego). Pierwotnie była wykorzystywana przez 16 członków spółdzielni, obecnie korzysta z niej ponad 60 tys. klientów. Walutę tę wykorzystuje około 17\% szwajcarskich przedsiębiorstw. Zgodnie ze statutem Swiss Economic Circle jej stworzenie miało na celu zachęcenie członków do wzajemnego wykorzystywania posiadanej siły nabywczej i utrzymywania jej w obiegu wśród swoich członków, zapewniając im tym samym dodatkową wielkość sprzedaży. Od 2004 roku zgodnie z normą ISO 4217 kodem tej waluty jest CHW. Waluta ta może być wykorzystywana do zapłaty za towary i usługi wyłącznie na terytorium Szwajcarii. Nie można nią regulować zobowiązań wobec budżetu państwa. Jednostką rozliczeniową franka WIR (CHW) jest frank szwajcarski 
(CHF) z parytetem jeden do jednego, chociaż zgodnie ze statutem WIR Banku nie jest możliwe dokonanie wymiany waluty WIR na franki szwajcarskie.

Należy zaznaczyć, że w Szwajcarii obok waluty WIR lokalne samorządy wprowadziły do obiegu takie waluty lokalne, jak np. Bonobo w Bernie (2015-2018), EulachTaler w Winterthur, Farinet w Unterwallis czy NetzBon w Bazylei. Na terytorium Belgii w obiegu znajduje się kilkadziesiąt walut lokalnych (www7), do których należą m.in.: Res, Torekes, Ropi, Eko-Iris, Blés, Talent, Carol'Or, Zinne. We Francji po 2010 roku do obiegu zostało wprowadzonych ponad 80 walut lokalnych. Aktualnie kilka kolejnych projektów jest w toku realizacji. Przykładem walut lokalnych funkcjonujących we Francji są m.in.: L'Abeille, Commune, Occitan, Roue, Eusko (Rébillard, 2019), Doume, Cairn, Gonette Pêche. W Wielkiej Brytanii idea wykorzystywania walut lokalnych zaczęła się rozwijać na początku XXI wieku. Jako przykłady takich inicjatyw można wskazać: Eko, Totnes Pound, Stroud Pound, Lewes Pound, Brixton Pound, Bristol Pound, Exeter Pound. Na Węgrzech pierwsza waluta lokalna Soproni Kékfrank została wyemitowana w 2010 roku. Ta udana emisja stała się impulsem dla powstania kolejnych walut lokalnych, takich jak: Balatoni Korona, Bocskai Korona (www1), Tokaji Dukat. W 2014 roku zostały wprowadzone do obrotu pierwsze waluty lokalne na Słowacji: Zvolenský živec, Košický dukát. W tym samym roku w Rosji pojawiła się waluta lokalna Kolion. Z kolei w Czechach w 2017 roku gmina Křižánky wprowadziła do obiegu walutę lokalną o nazwie Křižánecká koruna. W Niemczech w obrocie znajduje się kilkadziesiąt walut lokalnych ${ }^{17}$. Najbardziej znaną z nich jest Chiemgauer, która znajduje się w obiegu w okręgach Rosenheim i Traunstein w Bawarii. Przykładami innych walut lokalnych w Niemczech są: Bethel-Euro, Coinstatt, Donautaler, Hallertauer, Pauer, Ronald. Również w Polsce znaleźli się entuzjaści wprowadzenia do obiegu waluty lokalnej. Przykładami takich działań są: waluta lokalna Dobry wprowadzona do obiegu w styczniu 2014 roku czy też stworzona w 2014 roku w Kielcach waluta lokalna o nazwie Piast oraz waluta lokalna o nazwie Zielony wprowadzona do obrotu w 2015 roku w trzech województwach: świętokrzyskim, małopolskim i mazowieckim.

Idea waluty lokalnej znalazła wielu zwolenników również na innych kontynentach. Jako przykład takich walut funkcjonujących w Ameryce Północnej można wskazać: BerkShares, Calagary Dollars, Detroit Community Scrip, Toronto Dollar.

\section{Metodyka i cel badań}

Empiryczna analiza poziomu znajomości zagadnień związanych z funkcjonowaniem waluty lokalnej wśród studiujących przedstawicieli młodego pokolenia mieszkańców Polski została przeprowadzona na grupie 784 ankietowanych w wieku od 18 do 25 lat. Badanie zostało wykonane przy pomocy kwestionariusza ankietowego w styczniu

\footnotetext{
${ }^{17}$ W 2016 roku w Niemczech w obrocie znajdowało się 46 walut lokalnych.
} 
i lutym 2020 roku. Było ono poprzedzone badaniem pilotażowym zrealizowanym w grudniu 2019 roku. W analizowanej grupie badawczej znajdowało się 467 kobiet (59,57\%) oraz 317 mężczyzn (40,43\%). Uczestniczący w badaniu respondenci zostali podzieleni na pięć segmentów ze względu na miejsce zamieszkania, na cztery segmenty ze względu na dochód na członka rodziny oraz na cztery segmenty ze względu na kierunek studiów. Struktura grupy badawczej została przedstawiona na rysunku 1.
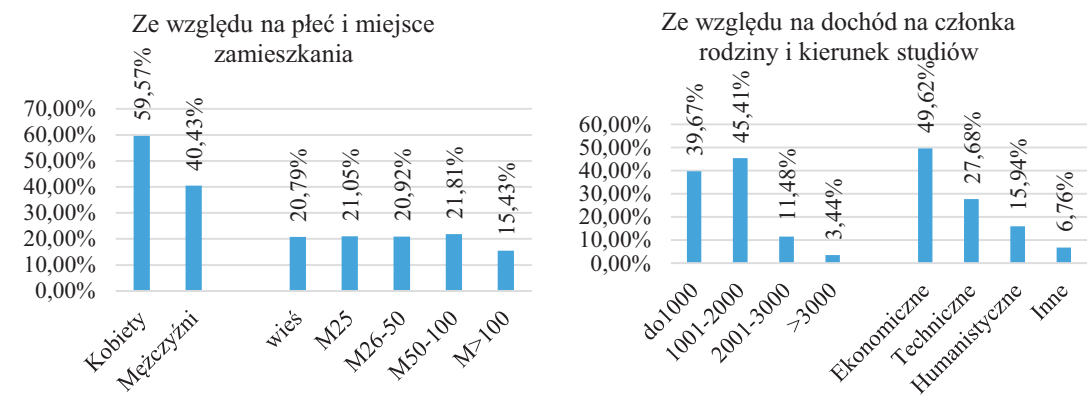

Rysunek 1. Struktura grupy badawczej

Źródło: opracowanie własne.

Podstawowym celem przeprowadzonych badań była próba określenia poziomu znajomości zagadnień związanych z funkcjonowaniem walut lokalnych wśród przedstawicieli młodego pokolenia mieszkańców Polski oraz zbadanie ich postawy odnośnie do wprowadzenia do obrotu takiej waluty.

\section{Ocena poziomu znajomości pojęcia waluty lokalnej}

Na wstępie badań uczestniczący w nich respondenci zostali poproszeni o określenie, czy znane jest im pojęcie waluty lokalnej (rysunek 2) oraz czy znają jakąś znajdującą się w obiegu walutę lokalną (rysunek 3). Uzyskane odpowiedzi pozwoliły stwierdzić, że pojęcie waluty lokalnej nie jest powszechnie znane. Jego znajomość zadeklarowało tylko $15,18 \%$ ankietowanych (15,63\% kobiet oraz $14,51 \%$ mężczyzn). Najwyższy odsetek badanych posiadających wiedzę na temat pojęcia waluty lokalnej występował wśród ankietowanych mieszkających w miastach powyżej 100 tys. mieszkańców $(23,97 \%)$, deklarujących dochód w przedziale od 2001 do 3000 PLN $(34,44 \%)$. Interesujące jest to, że nie wśród studentów kierunków ekonomicznych (15,42\%), lecz wśród studentów studiów technicznych $(20,28 \%)$ znajdowało się więcej ankietowanych, którzy zadeklarowali znajomość pojęcia waluty lokalnej. Fakt ten pozwolił obalić hipotezę, że to właśnie przedstawiciele kierunków ekonomicznych mają najwyższy poziom wiedzy na temat tego zagadnienia $\mathrm{z}$ obszaru rynków finansowych. 


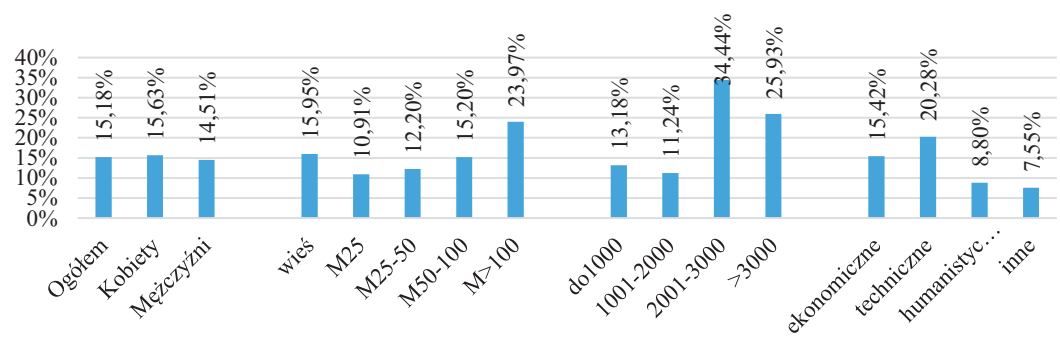

Rysunek 2. Poziom znajomości pojęcia waluty lokalnej wśród respondentów

Źródło: opracowanie na podstawie badań własnych.

Uwzględniając fakt, że waluty lokalne bardzo rzadko można spotkać w obiegu płatniczym, nie dziwi to, że tylko $8,04 \%$ respondentów $(7,71 \%$ kobiet oraz $8,52 \%$ mężczyzn) wskazało znajomość jakiejkolwiek znajdującej się w obiegu waluty lokalnej (rysunek 3). Najczęściej znajomość taką deklarowali studenci będący mieszkańcami dużych miast powyżej 100 tys. mieszkańców $(10,74 \%)$, o dochodzie w przedziale od 2001 do 3000 PLN (17,78\%), studiujący na kierunkach ekonomicznych (10,28\%).

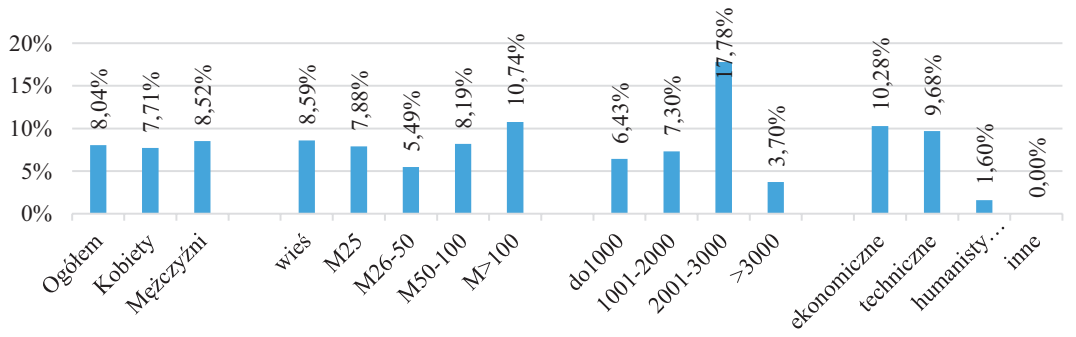

Rysunek 3. Poziom znajomości znajdujących się w obiegu walut lokalnych wśród respondentów

Źródło: opracowanie na podstawie badań własnych.

Należy podkreślić, że chociaż waluty lokalne bardzo rzadko występują w obiegu, to $0,89 \%$ ankietowanych $(0,64 \%$ kobiet oraz $1,26 \%$ mężczyzn) zadeklarowało, że dokonywali płatności przy pomocy takiej waluty. Wśród walut, przy pomocy których ankietowani zadeklarowali dokonanie płatności, znajdowały się Bristol Pound oraz Košický dukát. Należy zaznaczyć, że w analizowanej grupie badawczej znajdowało się też 2,93\% ankietowanych, którzy stwierdzili, że posiadają monety lokalne honorowane przez część podmiotów w miejscowościach turystycznych w okresach wakacyjnych. 


\section{Opinia respondentów na temat wprowadzenia do obiegu waluty lokalnej}

Większość uczestniczących w badaniach przedstawicieli młodego pokolenia studiujących mieszkańców Polski nie była zainteresowana wprowadzeniem do obiegu drugiej, równolegle funkcjonującej waluty w postaci waluty lokalnej (rysunek 4). Tylko około $29 \%$ ankietowanych uznało, że taką walutę należy wprowadzić do obiegu. Większe zainteresowanie posługiwaniem się walutą lokalną było wśród mężczyzn (31,86\%) niż wśród kobiet (27,2\%). Uwzględniając miejsce zamieszkania respondentów, stwierdzono, że najwięcej osób zainteresowanych wprowadzeniem do obiegu waluty lokalnej mieszkało w dużych miastach (w miastach 50-100 tys. $-34,5 \%$, w miastach powyżej 100 tys. - 31,41\%), a najmniej - na wsi (21,47\%).

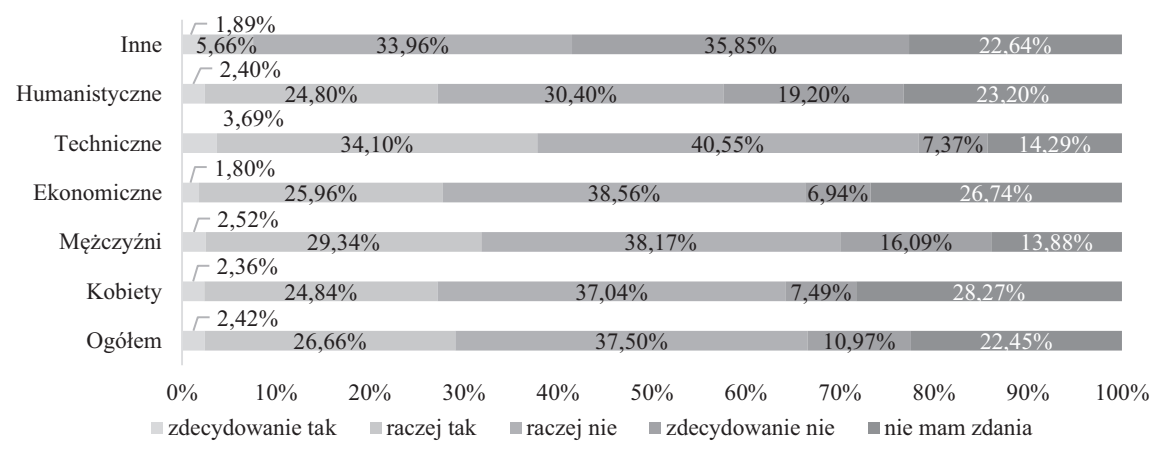

Rysunek 4. Opinia ankietowanych na temat wprowadzenia do obiegu waluty lokalnej

Źródło: opracowanie na podstawie badań własnych.

Z kolei uwzględniając dochód, stwierdzono, że największa grupa zwolenników wprowadzenia waluty lokalnej znajdowała się wśród ankietowanych posiadających dochód w przedziale od 2001 do 3000 PLN (36,67\%), a najmniejsza wśród respondentów o dochodzie powyżej 3000 PLN (18,52\%). Natomiast uwzględniając kierunek studiów, najwięcej respondentów zainteresowanych wprowadzeniem waluty lokalnej było wśród studentów kierunków technicznych (37,79\%).

W dalszej części badań zapytano ankietowanych o ich preferencje dotyczące formy, w jakiej chcieliby się posługiwać walutą lokalną, gdyby została wprowadzona do obiegu gospodarczego (rysunek 5). Jak przystało na przedstawicieli pokolenia ery bankowości elektronicznej, opowiedzieli się oni za nowoczesnymi, elektronicznymi formami jej emisji. Prawie połowa respondentów stwierdziła, że waluta lokalna powinna być emitowana wyłącznie w formie elektronicznej, a ponad $20 \%$ ankietowanych obok jej emisji w formie elektronicznej dopuściło również emisję $\mathrm{w}$ formie fizycznej. Trzeba w tym miejscu nadmienić, że zauważalna była rozbieżność opinii na ten temat wśród kobiet i mężczyzn. $Z$ waluty lokalnej wyłącznie w formie elektronicznej chciało korzystać 56,1\% kobiet oraz 39,43\% mężczyzn, natomiast za 
możliwością korzystania z niej w formie elektronicznej lub fizycznej opowiedziało się 29,34\% mężczyzn oraz 16,49\% kobiet. Zaznaczenia wymaga fakt, że największe zainteresowanie posługiwaniem się walutą lokalną wyłącznie w formie elektronicznej było wśród ankietowanych będących mieszkańcami dużych miast powyżej 100 tys. mieszkańców (55,37\%), deklarujących posiadanie dochodu powyżej 3000 PLN $(62,96 \%)$ oraz studiujących na kierunkach ekonomicznych $(63,75 \%)$.

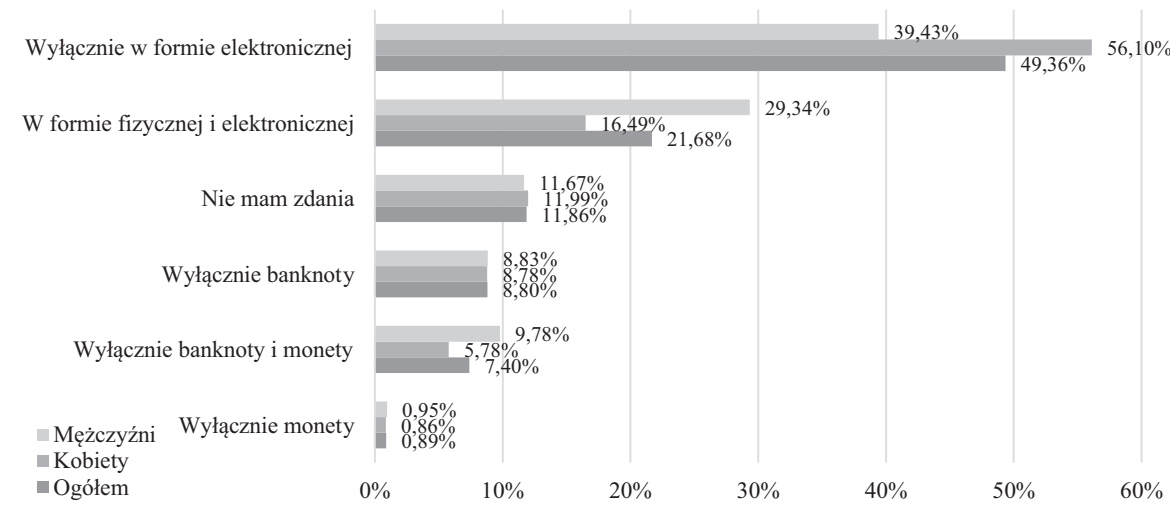

Rysunek 5. Preferowana przez ankietowanych forma wprowadzenia do obiegu waluty lokalnej

Źródło: opracowanie na podstawie badań własnych.

Prawie $85 \%$ przedstawicieli studentów uczestniczących w badaniach uznało, że wysokość płatności regulowanych przy pomocy waluty lokalnej powinna być odgórnie ograniczona. Opinię taką najczęściej wyrażali mieszkańcy wsi $(92,64 \%)$, ankietowani o dochodach ponad 3000 PLN (96,3\%) oraz respondenci studiujący na kierunkach ekonomicznych (91,52\%). Co ósmy ankietowany uważał, że limit ten powinien być ustalony na poziomie 1000 PLN, co piąty respondent wskazał na kwotę 5000 PLN, a co trzeci był zdania, że kwota ta może wynosić maksymalnie 10000 PLN (rysunek 6). Należy zaznaczyć, że najwięcej zwolenników ustalania limitów płatności na poziomie nieprzekraczającym 10000 PLN znajdowało się wśród mieszkańców wsi ${ }^{18}$, a także osób, które osiągały dochody na poziomie do 1000 PLN $^{19}$ oraz ankietowanych studiujących na kierunkach ekonomicznych ${ }^{20}$.

18 Wśród ankietowanych będących mieszkańcami wsi 13,91\% badanych wskazało na kwotę 1000 PLN, $25,17 \%$ na kwotę 5000 PLN, a 39,07\% na kwotę 10000 PLN.

19 Wśród respondentów osiągających dochód poniżej 1000 PLN 13,97\% badanych wskazało na kwotę 1000 PLN, 22,06\% respondentów na kwotę 5000 PLN, a 38,87\% na kwotę 10000 PLN.

${ }_{20}$ Wśród uczestników badań studiujących na kierunkach ekonomicznych $12,36 \%$ badanych wskazało na kwotę 1000 PLN, 27,25\% respondentów na kwotę 5000 PLN, a 34,55\% na kwotę 10000 PLN. 


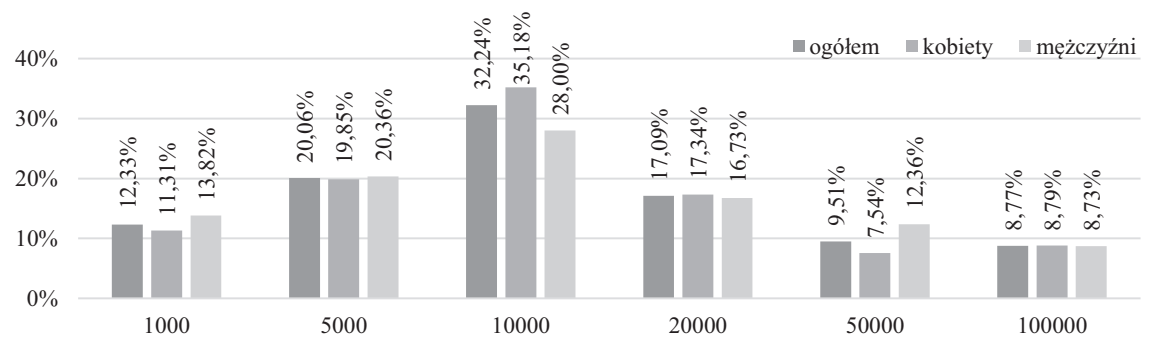

Rysunek 6. Sugerowana przez ankietowanych maksymalna wysokość limitu płatności regulowanych przy pomocy waluty lokalnej

Źródło: opracowanie na podstawie badań własnych.

Ponadto uczestniczący w badaniach respondenci stwierdzili, że emisję takiej waluty należałoby powierzyć podmiotom posiadającym wysoki poziom zaufania społecznego (rysunek 7), które mogą zagwarantować utrzymanie siły nabywczej waluty lokalnej, czyli jednostkom samorządu terytorialnego (55,74\%) lub ministrowi wyznaczonemu przez rząd $(53,44 \%)$. Podmioty te częściej były wskazywane przez mężczyzn niż przez kobiety (odpowiednio w przypadku JST - 59,94\% i 52,89\%, a w przypadku wyznaczonego przez rząd ministra - 63,72\% i 46,47\%). Co dziewiąty ankietowany wskazał również na niższego rangą przedstawiciela rządu, czyli wojewodę. Należy zaznaczyć, że podmioty te najczęściej były wymieniane przez ankietowanych studiujących na kierunkach technicznych (wyznaczony przez rząd minister $-70,51 \%$, JST $-61,29 \%$, wojewoda $-16,13 \%$ ).

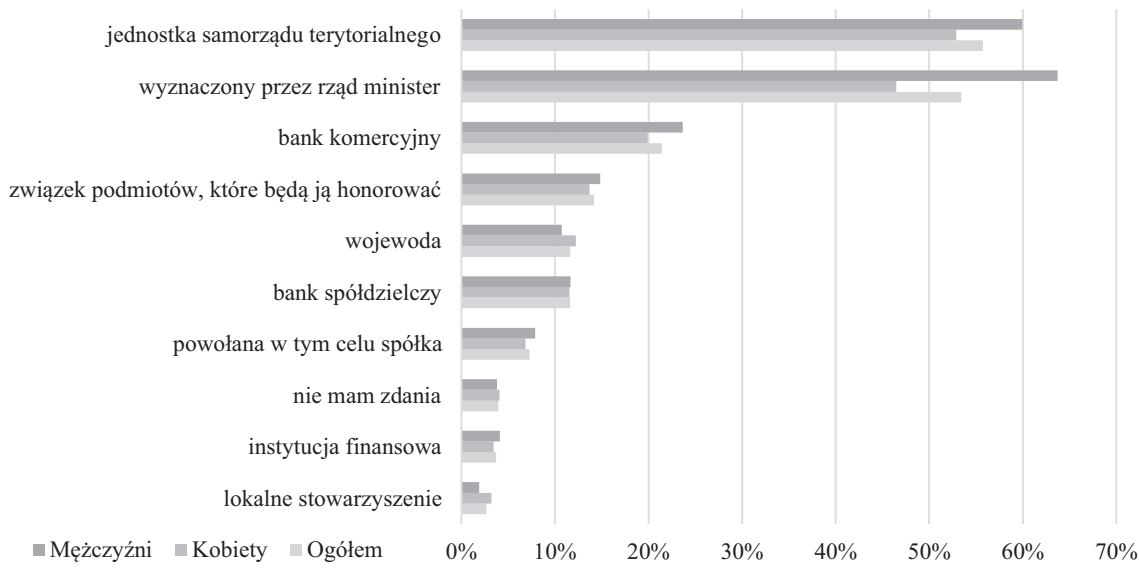

Rysunek 7. Podmioty, które zdaniem ankietowanych mogą być emitentami waluty lokalnej Źródło: opracowanie na podstawie badań własnych.

Znaczna część respondentów uznała, że zadania związane z emisją waluty lokalnej powinny zostać powierzone podmiotom $\mathrm{z}$ sektora finansowego: bankom komer- 
cyjnym $^{21}(21,43 \%)$, bankom spółdzielczym ${ }^{22}(11,61 \%)$ lub instytucjom finansowym $(3,7 \%)$. Natomiast co siódmy ankietowany stwierdził, że emitentem waluty lokalnej powinien być związek podmiotów, które wyraziły zgodę na przyjmowanie w niej zapłaty, a co czternasty badany wskazał, że należy do realizacji tego przedsięwzięcia powołać specjalną spółkę.

Według zdecydowanej większości uczestników badań (87,12\%, w tym 88,65\% kobiet oraz $84,86 \%$ mężczyzn) kurs waluty lokalnej powinien być na sztywno powiązany z walutą krajową (rysunek 8). Opinię taką najczęściej wyrażali respondenci mieszkający na wsi $(90,18 \%)$ oraz ankietowani posiadający dochody w przedziale od 1001 do 2000 PLN (89,89\%) i w przedziale do 1000 PLN (89,71\%). Należy podkreślić, że takiego zdania było aż 92,28\% ankietowanych studiujących na kierunkach ekonomicznych.

Z kolei możliwość powiązania kursu waluty lokalnej z wybraną walutą międzynarodową zaakceptowało 30,61\% respondentów (30,41\% kobiet oraz 30,92\% mężczyzn). Taka forma ustalania kursu waluty lokalnej najczęściej była proponowana przez ankietowanych mieszkających w dużych miastach (50-100 tys. mieszkańców $33,33 \%$, powyżej 100 tys. mieszkańców - 33,06\%) oraz respondentów o dochodach powyżej 3000 PLN (48,15\%). Najczęściej wskazywali na nią respondenci studiujący na kierunkach technicznych $(34,56 \%)$.

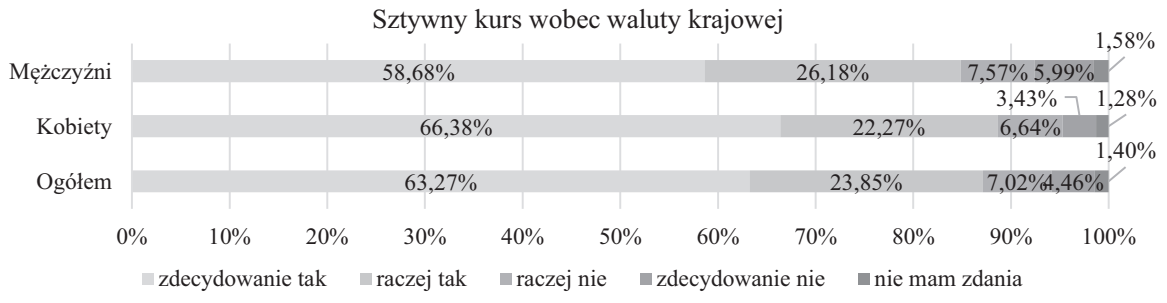

Sztywny kurs wobec waluty międzynarodowej

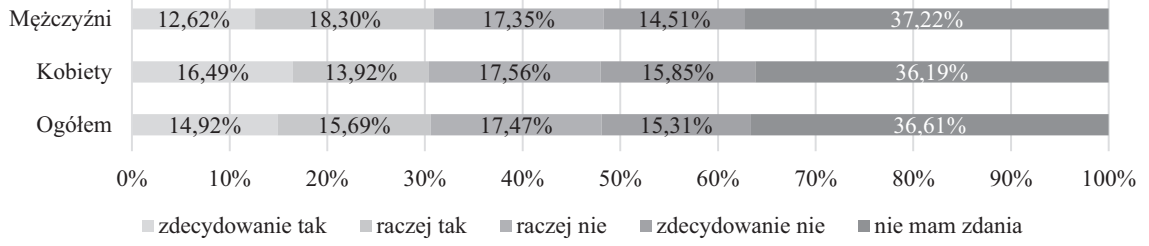

Rysunek 8. Opinia ankietowanych na temat powiązania kursu waluty lokalnej z walutą krajową i walutą międzynarodową

Źródło: opracowanie na podstawie badań własnych.

21 Powierzenie emisji waluty lokalnej bankom komercyjnym miało najwięcej zwolenników wśród mieszkańców miast od 50 do 100 tys. mieszkańców (26,9\%).

22 Powierzenie emisji waluty lokalnej bankom spółdzielczym miało najwięcej zwolenników wśród respondentów mieszkających na wsi $(15,34 \%)$ oraz w małych miastach do 25 tys. mieszkańców $(13,33 \%)$. 
Następnie respondenci określili poziom zainteresowania realizacją płatności przy wykorzystaniu waluty lokalnej (rysunek 9) oraz wskazali miejsca, w których powinna być możliwość realizacji płatności w takiej walucie (rysunek 10).

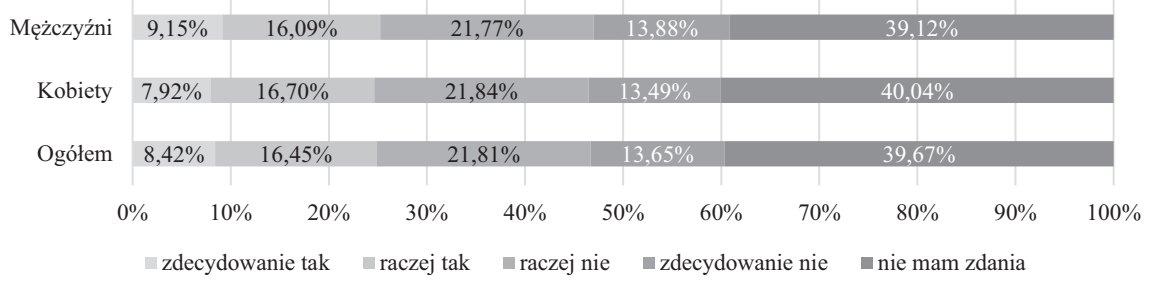

Rysunek 9. Chęć realizacji płatności przez respondentów przy pomocy waluty lokalnej

Źródło: opracowanie na podstawie badań własnych.

Chęć wykorzystywania waluty lokalnej (jeżeli istniałaby taka możliwość) do realizacji płatności zadeklarował co czwarty badany (24,62\% kobiet oraz 25,24\% mężczyzn). Najwięcej respondentów, którzy zgłosili gotowość korzystania z waluty lokalnej, mieszkało w miastach powyżej 100 tys. mieszkańców (36,36\%) oraz osiągało dochody w przedziale od 2001 do 3000 PLN (33,33\%). Należy zaznaczyć, że największe zainteresowanie realizacją płatności przy wykorzystaniu waluty lokalnej zgłosili respondenci studiujący na kierunkach technicznych $(27,19 \%)$, a najmniejsze - na kierunkach ekonomicznych (22,88\%).

Zgodę na otrzymywanie wynagrodzenia w walucie lokalnej wyraziłoby tylko $8,41 \%$ respondentów ${ }^{23}$. Należy podkreślić, że aż $77,8 \%$ ankietowanych ${ }^{24}$ zadekla- $^{-}$ rowało, że nie zaakceptują takiej formy zapłaty za pracę.

Blisko $60 \%$ ankietowanych stwierdziło, że możliwość realizacji płatności przy pomocy waluty lokalnej powinna być zapewniona w barach i restauracjach (rysunek 10). Ponad połowa respondentów wskazała na muzea oraz atrakcje turystyczne, a ponad $48 \%$ - na hotele. Aż $40 \%$ badanych uznało, że taką walutę powinny honorować sklepy, a co trzeci respondent wskazał na punkty usługowe. Należy jednak zaznaczyć, że tylko około 15\% uczestników badań dopuściłoby możliwość regulowania opłat urzędowych za pomocą takiej waluty.

${ }^{23}$ Na odpowiedź zdecydowanie tak wskazało 2,93\% ankietowanych, a 5,48\% respondentów wybrało odpowiedź raczej tak. Najniższy poziom zainteresowania taką formą zapłaty za pracę wystąpił w segmencie respondentów studiujących na kierunkach ekonomicznych $(6,68 \%)$.

${ }^{24}$ Na odpowiedź zdecydowanie nie wskazało 48,34\% respondentów, a 29,46\% respondentów wybrało odpowiedź raczej nie. 


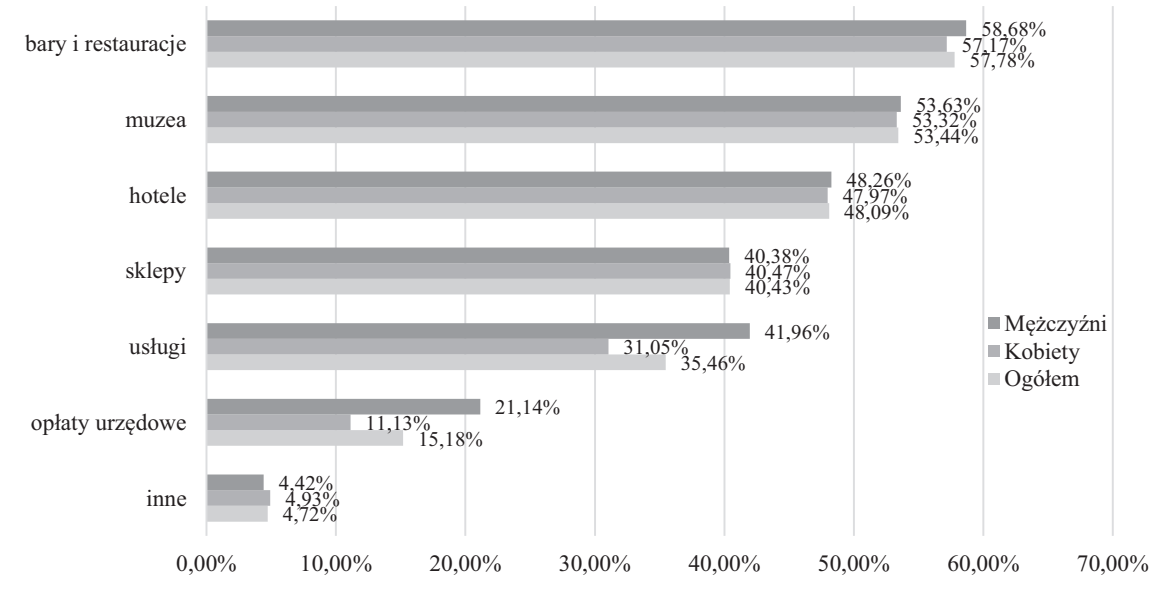

Rysunek 10. Miejsca, w których zdaniem respondentów powinna być możliwość realizacji płatności walutą lokalną

Źródło: opracowanie na podstawie badań własnych.

\section{Podsumowanie}

Wprowadzenie do obiegu waluty lokalnej nie może być uważane za antidotum w czasach kryzysu, które skutecznie może wpłynąć na pobudzenie lokalnej przedsiębiorczości, zwiększenie wykorzystania lokalnych możliwości produkcyjnych czy zmniejszenie poziomu bezrobocia.

Entuzjaści emisji waluty lokalnej muszą mieć świadomość, że ten eksperyment gospodarczy, chociaż w ostatnich dziesięcioleciach na całym świecie występuje coś w rodzaju mody na jego wprowadzanie, odniósł sukces w niewielkiej liczbie regionów, które go wdrożyły. Nie mogą więc patrzeć na wprowadzenie waluty lokalnej jedynie przez pryzmat kilku przypadków, w których odniosła ona, zazwyczaj krótkookresowy, sukces. Należy uwzględnić fakt, że niewielki odsetek spośród kilku tysięcy walut lokalnych znajdował się w obiegu przez okres co najmniej pięciu lat, a jeszcze mniejsza ich liczba przyczyniła się do znaczącej poprawy sytuacji gospodarczej regionu objętego zasięgiem takiej emisji w dłuższym okresie.

Przystępując do prac nad wprowadzeniem waluty lokalnej, należy mieć na uwadze, że sukces takich działań zależy zarówno od czynników organizacyjno-ekonomicznych, jak i psychologiczno-społecznych. O powodzeniu tych działań może zadecydować z jednej strony stworzenie wiarygodnego systemu obrotu tą walutą ${ }^{25}$

25 Taki system powinien nie tylko umożliwiać sprawne posługiwanie się walutą lokalną wszystkim akceptującym ją podmiotom gospodarczym i konsumentom, ale również dawać gwarancję władzom, że taki obrót nie ma żadnych powiązań z działalnością przestępczą, np. z próbą omijania płacenia podatków. 
czy właściwe określenie poziomu wielkości emisji ${ }^{26}, \mathrm{z}$ drugiej zaś przygotowanie społeczeństwa do posługiwania się równocześnie walutą narodową i walutą lokalną.

Przeprowadzone badania pozwoliły stwierdzić, że wśród przedstawicieli młodego pokolenia mieszkańców Polski zagadnienia związane z funkcjonowaniem waluty lokalnej są znane w minimalnym stopniu. Tylko co siódmy ankietowany znał pojęcie waluty lokalnej, a co dwunasty zadeklarował znajomość jakiejś waluty lokalnej znajdującej się w obiegu gospodarczym. Zdaniem prawie połowy uczestników badań w miejscu ich zamieszkania nie ma potrzeby wprowadzania dodatkowej waluty uzupełniającej, a tylko około $2,5 \%$ ankietowanych uznało, że zdecydowanie należałoby ją wprowadzić.

Uczestnicy badania przykładali dużą wagę do bezpieczeństwa posługiwania się walutą lokalną. Ponad połowa ankietowanych stwierdziła, że emitentami takiej waluty powinny być podmioty posiadające wysoki poziom zaufania społecznego oraz gwarancje państwowe zapewniające utrzymanie siły nabywczej tej waluty. Bardzo istotna była dla nich również forma, w jakiej mogliby dokonywać płatności. Według ponad $71 \%$ badanych najlepsza do realizacji transakcji przy pomocy waluty lokalnej jest forma elektroniczna. Niemal 85\% respondentów wskazało, że powinna zostać ustalona maksymalna kwota płatności przy pomocy waluty lokalnej; zdaniem prawie dwóch trzecich badanych kwota ta powinna być stosunkowo niska, mniejsza niż 10000 PLN.

Należy zaznaczyć, że przedstawiciele młodego pokolenia mieszkańców Polski są pozytywnie nastawieni do wszelkiego rodzaju nowinek, w tym do innowacji na rynku finansowym. Pomimo bardzo niskiego poziomu wiedzy na temat funkcjonowania walut lokalnych prawie $25 \%$ badanych zadeklarowało chęć dokonywania płatności w takiej walucie, a 8,4\% ankietowanych dopuściło możliwość otrzymywania w niej wynagrodzenia. Pozwala to na stwierdzenie, że w Polsce istnieją duże możliwości rozwoju walut lokalnych, ale działania mające na celu ich wprowadzenie muszą zostać poprzedzone zakrojoną na szeroką skalę akcją informacyjno-edukacyjną.

Podsumowując, należy podkreślić, że podejmowane działania związane z wprowadzeniem do obiegu waluty lokalnej powinny mieć na celu rzeczywisty rozwój gospodarczy danej społeczności, a nie stanowić jedynie krótkookresową ciekawostkę kolekcjonerską. Waluta lokalna powinna być akceptowalnym na lokalnym rynku środkiem płatniczym, a nie pamiątką turystyczną dającą jedynie jednorazowy dochód jej emitentowi.

${ }^{26}$ W praktyce niezwykle skomplikowanym zadaniem jest określenie optymalnego dla danego regionu poziomu wielkości emisji waluty lokalnej, który z jednej strony zapewniałby możliwość dynamicznego rozwoju gospodarczego, z drugiej zaś nie miałby wpływu na pojawianie się zjawisk negatywnych, np. inflacji. 


\section{Bibliografia}

\section{Literatura}

Collom, E. (2011). Motivations and differential participation in a community currency system: The dynamics within a local social movement organization. Sociological Forum, 26(1), 144-168. doi:10.1111/j.1573-7861.2010.01228.x

Kennedy, M., \& Lietaer, B. (2004). Regional-währungen. München: Riemann.

Kennedy, M., Lietaer, B., \& Rogers J. (2012). People Money: The Promise of Regional Currencies. London: Triarchy Press.

Lietaer, B. (1999). Das Geld der Zukunft. München: Riemann.

Lietaer, B. (2004). Complementary Currencies in Japan Today: History, Originality and Relevance. International Journal of Community Currency Research, 8, 1-23.

Ranalli, B. (2013). Local Currencies: A Potential Solution for Liquidity Problems in Refugee Camp Economies. Journal of Refugee Studies, 26(4), 422-433. doi:10.1093/jrs/fet049

Sołtysiak, M. (2020). Rynek walutowy - pojęcia i ćwiczenia. Rzeszów: Oficyna Wydawnicza Politechniki Rzeszowskiej.

Tóth, I.B. (2011). The Function of Local Currencies in Local Economic Development. Public Finance Quarterly, State Audit Office of Hungary, 56(1), 67-78.

Volkmann, K. (2012). Solidarity economy between a focus on the local and a global view. International Journal of Community Currency Research, 16(D), 97-105.

\section{Netografia}

Rébillard, C. (2019). L'eusko basque, première monnaie locale européenne. Pobrane z: https://reporterre. net/L-eusko-basque-premiere-monnaie-locale-europeenne

Swann, R., \& Witt, S. (1995). Local Currencies: Catalysts for Sustainable Regional Economies. Pobrane z: www.complementarycurrency.org/ccLibrary/materials/local_currencies_catalysts.pdf

www1: www.bocskaikorona.hu

www2: www.economie.gouv.fr/files/loi_ess_mesures.pdf

www3: www.energiemetropole.at/information/sehenswuerdigkeiten/freigeld

www4: www.heimat.woergl.at/verschiedenes/freigeld-woergl

www5: www.ooegeschichte.at/themen/politik-recht-und-gesellschaft/der-rest-ist-oesterreich/wirtschaft/ woergler-schilling

www6: www.rtl.fr/actu/conso/une-nouvelle-monnaie-doit-rentrer-en-circulation-a-paris-7788396230

www7: www.solatoi.be/les-monnaies-locales-en-belgique-et-plus

www8: www.unterguggenberger.org/woergler-freigeld-historisch 